\title{
IMPLEMENTASI ALGORITME BOYER-MOORE PADA APLIKASI KAMUS ISTILAH KOMPUTER BERBASIS ANDROID
}

\author{
Muhammad Husni Rifqo ${ }^{1}$, Andilala ${ }^{2}$ \\ ${ }^{1,2}$ Program Studi Informatika, Fakultas Teknik, Universitas Muhammadiyah Bengkulu \\ Jl. Bali PO BOX 118. Telp (0736) 227665, Fax (0736) 26161, Bengkulu 38119 \\ ${ }^{1}$ mhrifqoeumb.ac.id \\ andilala@umb.ac.id
}

Abstrak: String Matching merupakan proses pencocokan string untuk menemukan kesamaan antara teks dan pattern. Pada proses pencarian kata pada aplikasi Kamus android terbilang sulit, dikarenakan banyaknya data didalam database, sehingga proses pencarian tersebut cukup lama jika dicari satu persatu. Untuk pemecahan masalah tersebut, salah satu algoritme string matching yang digunakan adalah algoritme Boyer-Moore karena algoritme ini merupakan algoritme string matching yang paling efesien dibandingkan algoritme-algoritme string matching lainnya. Tujuan penelitian ini ialah menerapkan algoritme Boyer-Moore pada aplikasi kamus komputer. Adapun manfaat penelitian ini diharapkan dapat mempermudah khususnya bagi mahasiswa Fakultas Teknik untuk mencari kata-kata istilah komputer untuk media pembelajaran. Diharapkan aplikasi ini mendapat tanggapan yang baik bagi pengguna supaya bisa dikembangkan lagi kedepannya. Aplikasi ini masih terdapat kekurangan dan dapat dikembangkan lagi kedepannya, seperti pencariannya tidak otomatis huruf besar dan kecilnya, bisa juga dikembangkan berbagai macam kamus lainnya seperti kamus obat, beladiri, bahasa daerah dan lain sebagainya.

Kata Kunci: String matching, Boyer-Moore, Aplikasi, Kamus, Android

Abstract: String Matching is a string matching process to find common ground between text and pattern. In the process of word search in android dictionary application is quite difficult, due to the number of data in the database, so the search process is long enough if searched one by one. To solve the problem, one of the string matching algorithms used is the Boyer-Moore algorithm because this algorithm is more efficient than other match string algorithm. The purpose of this research is to apply the Boyer-Moore algorithm to computer dictionary application. The benefits of this study is expected to facilitate, especially for students of the Faculty of Engineering to search for words of computer terms for learning media. It is expected that this application gets a good response for users to be developed again in the future. This application is still there are deficiencies and can be developed again in the future, such as search is not automatically capitalized and small, can also be developed various other dictionaries such as drug dictionary, martial arts, regional languages and so forth.

Keywords: String matching, Boyer-Moore, Applications, Dictionary, Android

\section{PENDAHULUAN}

Kamus menurut KBBI (Kamus Besar Bahasa Indonesia) merupakan buku acuan yang memuat kata dan ungkapan yang biasanya disusun menurut abjad berikut keterangan dan makna, pemakaian, atau terjemahannya. Selain itu, kamus merupakan buku yang memuat kumpulan istilah atau nama yang disusun menurut abjad beserta dengan penjelasan makna dan pemakaiannya [1]. Kamus 
memiliki berbagai macam jenis, sesuai dengan isi yang terkandung didalamnya. Ada kamus istilah, dan ada juga jenis kamus yang menjadi pedoman disiplin ilmu tertentu, misalnya kamus satwa, kamus kedokteran, kamus bahasa daerah, dan kamus komputer.

Kamus komputer merupakan kamus yang mencakup istilah-istilah didalam komputer termasuk didalamnya software, hardware dan pendukung lainnya. Kamus komputer berupa aplikasi sangat praktis dimana untuk menemukan suatu istilah didalam dunia komputer tidak perlu lagi susah membawa buku kamus yang sangat tebal atau membawa beberapa macam buku untuk menemukan suatu pengertian dari istilah komputer itu sendiri, dan tentunya lebih mudah didalam pencarian dan mempersingkat waktu dalam penggunaanya.

Proses pencarian pada kamus istilah komputer sangat bermanfaat, namun proses pencarian itu lambat dan membutuhkan waktu yang lebih lama. Untuk mempercepat dan mempermudah suatu proses pencarian, dibutuhkan algoritme untuk memaksimalkan proses pencarian tersebut. Algoritme adalah urutan langkah-langkah logis untuk menyelesaikan suatu persoalan, deretan instruksi yang jelas untuk memecahkan persoalan, yaitu untuk memperoleh luaran yang diinginkan dari suatu masukan dalam jumlah waktu yang terbatas [2]. Algoritme untuk pencarianpun sudah semakin berkembang dari hari ke hari. Algoritme pencarian yang dianggap memiliki hasil paling baik dalam praktiknya, yaitu algoritme yang bergerak mencocokan string dari arah kanan kekiri. Algoritme Boyer-Moore merupakan salah satu contoh algoritme yang menggunakan arah dari kanan ke kiri [3].

Pada penelitian Halim Agung menyatakan algoritme Boyer-Moore dianggap sebagai algoritme pencocokan string yang paling efisien digunakan dalam berbagai aplikasi sehari-hari. Algoritme Boyer-Moore melakukan perbandingan antara pattern yang dicari dengan teks. Perbandingan pattern dengan teks dilakukan dari arah kanan kekiri. Kelebihan dari algoritme BoyerMoore ini ialah semakin panjang pola yang dicari maka waktu pencarian akan semakin singkat. Sedangkan kekurangan algoritme Boyer-Moore adalah lebih lambat untuk pattern yang pendek dan tidak baik untuk pencarian binnary string.Penelitian ini memperioritaskan kemudahan dan kecepatan khususnya bagi mahasiswa Teknik Informatika dalam mencari istilah-istilah komputer.

Tujuan penelitian ini ialah melakukan implementasi Algoritme Boyer-Moore pada aplikasi kamus istilah komputer berbasis android.

Adapun manfaat dari penelitian ini adalah memberikan kemudahan kepada mahasiswa mahasiswa dalam mencari istilah istilah komputer, dan kemudahan ini didapatkan karena kamus istilah tersebut bisa diaplikasikan pada ponsel yang berbasis android. Dan dari aplikasi ini diharapkan dapat mempersingkat waktu dalam pencarian istilah komputer yang berbeda dengan kamus umum lainnya.

Batasan dari penelitian ini adalah aplikasi ini berbasis android dan menggunakan basis data SQLite. Pada pencarian aplikasi kamus istilahistilah komputer hanya terbatas pada bebrapa kata yang sudah dikategorikan yaitu perangkat keras (Hardware), perangkat lunak (Software), dan perangkat pendukung lainnya. Istilah komputer yang dimasukan akan dikenali apabila sudah dimasukkan dalam basis data. 


\section{TINJAUAN PUSTAKA}

\section{A. Implemetasi}

Implementasi adalah bermuara pada aktivitas, aksi, tindakan, atau adanya mekanisme suatu sistem. Implementasi bukan sekedar aktivitas, tetapi suatu kegiatan yang terencana dan untuk mencapai tujuan kegiatan. Implementasi adalah perluasan aktivitas yang saling menyesuaikan proses interaksi antara tujuan dan tindakan untuk mencapainya serta memerlukan jaringan pelaksana, birokrasi yang efektif [4].

Implementasi merupakan proses untuk memastikan terlaksananya suatu kebijakan dan tercapainya kebijakan tersebut. Impelementasi juga dimaksudkan menyediakan sarana untuk membuat sesuatu dan memberikan hasil yang bersifat praktis terhadap sesama [5]. Sedangkan menurut [6] implementasi adalah penerapan dari sebuah sistem informasi yang telah diterapkan pada sebuah program komputer.

Jadi Implementasi merupakan tindakan, mekanisme sistem untuk mencapai suatu tujuan kegiatan yang saling menyesuaikan proses interaksi antara tujuan dan tindakan untuk tercapainya suatu hasil yang bersifat praktis terhadap sesama.

\section{B. Algoritme Boyer-Moore}

Ide utama dari algoritme ini adalah dengan melakukan pencocokan dari paling kanan string yang dicari. Dengan menggunakan algoritme ini, secara rata-rata proses pencarian akan lebih cepat dibandingkan dengan proses pencarian lainnya. Ide dibalik algoritme ini adalah bahwa dengan memulai pencocokan karakter dari kanan, dan bukan dari kiri, maka akan lebih banyak informasi yang didapat [7]. Algoritme Boyer-Moore termasuk algoritme string matching yang paling efesien dibandingkan algoritme-algoritme string matching lainnya. Algoritme Boyer-Moore mulai mencocokkan karakter dari sebelah kanan pattern, karena akan lebih banyak informasi yang didapat. Algoritme Boyer-Moore menggunakan dua fungsi shift yaitu good-suffix dan bad-character shift [8].

Secara sistematis, langka-langkah yang dilakukan algoritme Boyer-Moore adalah:

1. Buat tabel pergeseran string yang dicari (S) dengan pendekatan Match Heuristic (MH) dan Occurence Heuristic $(\mathrm{OH})$, untuk menentukan jumlah pergeseran yang akan dilakukan jika mendapat karakter tidak cocok pada proses pencocokan dengan string $(\mathrm{T})$.

2. Jika dalam proses pembandingan terjadi ketidakcocokan antara pasangan karakter pada $\mathrm{S}$ dan karakter pada $\mathrm{T}$, pergeseran dilakukan dengan memilih salah satu nilai pergeseran dari dua tabel analisa string, yang memiliki nilai pergeseran paling besar.

3. Dua kemungkinan penyelesaian dalam melakukan pergeseran S, jika sebelumnya belum ada karakter yang cocok adalah dengan melihat nilai pergeseran hanya pada tabel occurence heuristic : Jika karakter yang tidak cocok tidak ada pada $\mathrm{S}$ maka pegeseran adalah sebanyak jumlah karakter pada S. dan jika karakter yang tidak cocok ada pada $S$, maka banyaknya pergeseran bergantung dari nilai pada tabel.

4. Jika karakter pada teks yang sedang dibandingkan cocok dengan karakter pada $\mathrm{S}$, maka posisi karakter pada $\mathrm{S}$ dan $\mathrm{T}$ diturunkan sebanyak 1 posisi, kemudian lanjutkan dengan pencocokan pada posisi tersebut dan seterusnya. Jika kemudian terjadi ketidakcocokan karakter $\mathrm{S}$ dan $\mathrm{T}$, maka pilih nilai pergeseran terbesar dari dua tabel analisa pattern yaitu nilai dari tabel match heuristic dan nilai tabel occurence heuristic dikurangi dengan jumlah karakter yang telah cocok. 
5. Jika semua karakter telah cocok, artinya $S$ telah ditemukan di dalam $\mathrm{T}$, selanjutnya geser pattern sebesar 1 karakter.

6. Lanjutkan sampai akhir string $\mathrm{T}$.

Algoritme kemudian menggeser pattern dengan memisalkan nilai pergeseran good-suffix dan pergeseran bad-character lalu mengulangi langkah 2 sampai pattern berada di ujung teks [8].

Tabel 1. Contoh Algoritme Boyer-Moore

\begin{tabular}{|l|l|l|l|l|l|l|l|l|l|l|}
\hline $\mathrm{M}$ & $\mathrm{A}$ & $\mathrm{K}$ & $\mathrm{A}$ & $\mathrm{N}$ & & $\mathrm{T}$ & $\mathrm{O}$ & $\mathrm{M}$ & $\mathrm{A}$ & $\mathrm{T}$ \\
\hline $\mathrm{T}$ & $\mathrm{O}$ & $\mathrm{M}$ & $\mathrm{A}$ & $\mathrm{T}$ & & & & & & \\
\hline
\end{tabular}

Penelitian Kencawa Wulan Argakusuma menyatakan dalam contoh diatas, dengan melakukan perbandingan dari posisi paling akhir string dapat dilihat bahwa karakter ' $\mathrm{n}$ ' Pada string "makan" tidak cocok dengan karakter " $t$ " pada string "tomat" yang dicari, dan karakter " $n$ " tidak perna ada dalam string "makan", sehingga posisinya seperti berikut:

Tabel 2. Contoh Algoritme Boyer-Moore.

\begin{tabular}{|l|l|l|l|l|l|l|l|l|l|l|}
\hline M & A & K & A & N & & T & O & M & A & T \\
\hline & & & & & T & O & M & A & T & \\
\hline
\end{tabular}

\section{Aplikasi}

Aplikasi berasal dari bahasa inggris, yaitu "To applicate" yang artinya menerapkan atau terapan. Namun pengertian mengenai aplikasi secara umum adalah suatu paket program yang sudah jadi dan dapat digunakan. Sedangkan arti aplikasi adalah "program komputer yang dibuat untuk menolong manusia dalam melaksanakan tugas tertentu" [9] Aplikasi berasal dari kata "application" yang artinya penerapan, lamaran, penggunaan. Secara istilah aplikasi adalah program siap pakai yang direka untuk melaksanakan suatu fungsi bagi pengguna atau aplikasi yang lain dan dapat digunakan oleh sasaran yang dituju. Perangkat lunak aplikasi adalah suatu subkelas perangkat lunak komputer yang memanfaatkan kemampuan komputer langsung untuk melakukan tugas yang diinginkan pengguna. Contoh utama perangkat lunak aplikasi adalah pengolah kata, lembar kerja, dan pemutar media [10].

Jadi aplikasi "application" merupakan suatu terapan, penerapan, dan penggunaan. Secara umum ialah suatu paket program siap pakai yang untuk melaksanakan suatu fungsi bagi pengguna atau aplikasi yang lain dapat digunakan oleh sasaran yang dituju.

\section{Kamus}

Kamus adalah sejenis buku rujukan yang menerangkan makna kata-kata. Ia berfungsi untuk membantu seseorang mengenal perkataan baru. Selain menerangkan maksud kata, kamus juga mungkin mempunyai pedoman sebutan, asal usul (etimologi) sesuatu perkataan dan juga contoh penggunaan bagi sesuatu perkataan. Untuk memperjelas kadang kala terdapat juga ilustrasi di dalam kamus [11]. Kamus istilah komputer merupakan kamus yang mencakup istilah-istilah komputer, termasuk didalamnya mengenai istilahistilah dalam perangkat lunak (software), perangkat keras (hardware), maupun perangkat pendukung.

\section{E. Android}

Android adalah sebuah sistem operasi untuk perangat mobile berbasis linux yang mencakup sistem operasi, middleware dan aplikasi. Android menyediakan platform terbuka bagi para pengembang untuk menciptakan aplikasi mereka. Awalnya, Google Inc. membeli Android Inc. yang merupakan pendatang baru yang membuat peranti lunak untuk ponsel atau smartphone. Lalu untuk mengembangkan Android, dibentuklah Open Handset Allience, konsorsium dari 34 perusahaan peranti keras, peranti lunak, dan telekomunikasi, termasuk Google, HTC, Intel, Motorola, Qualcomm, T-Mobile, dan Nvidia. Android dirilis pada 5 November 2007, Android bersama Open Handset Allience menyatakan mendukung 
pengembangan open source pada perangkat mobile. Didunia ini terdapat dua jenis distributor sistem operasi Android. Pertama yang mendapat dukungan penuh dari Google Mail Services (GMS) dan kedua adalah yang benar-benar bebas distribusinya tanpa dukungan langsung Google atau dikenal sebagai Open Handset Distribution (OHD) [12].

\section{METODE PENELITIAN}

Di dalam penelitian ini, pengumpulan data dilakukan dengan metode kepustakaan. Dimana pengumpulan data dilakukan dengan mencari referensi dan literature berupa buku, jurnal, artikel skripsi baik dicetak maupun besifat online. penelitian tidak dilakukan terkhusus di suatu tempat atau Istansi manapun karena merupakan studi pustaka (kepustakaan) yang dilakukan sendiri dengan membaca buku-buku, jurnal, artikel skripsi dan laiinya guna mengumpulkan data.

\section{F. Model Pengembangan Sistem}

Dalam penelitian ini pengembangan sistem ini dilakukan dengan menggunakan model incremental, incremental dalam rekayasa perangkat lunak menerapkan rekayasa perangkat lunak perbagian, hingga menghasilkan perangkat lunak yang lengkap. Proses pembangunan berhenti jika produk telah mencapai seluruh fungsi yang diharapkan. Model ini terdiri dari proses analisis, desain, kode dan pengujian/testing.

\section{G. Perancangan Sistem}

Pada rancangan antarmuka Home ini adalah saat pertama kali aplikasi ini dijalankan, tampilan ini berisi logo dari aplikasi ini.

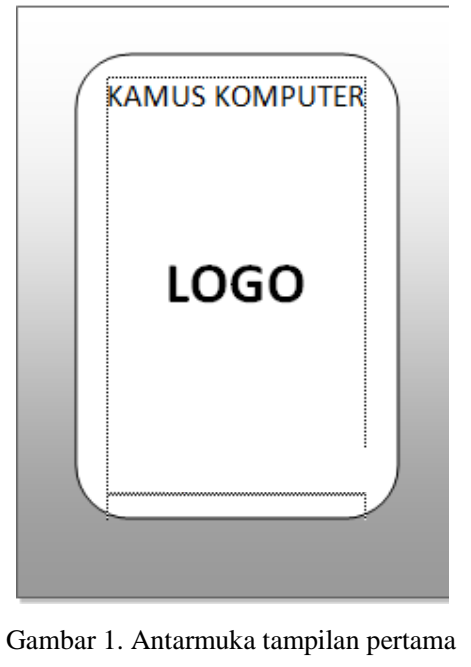

Pada halaman menu utama terdapat empat menu pilihan yang direpresentasikan dengan tombol yang berfungsi sebagai navigasi ke halaman lainnya, yaitu Kamus, Informasi, Bantuan,dan Keluar. Adapun rancangan antarmuka dari menu utama ialah sebagai berikut:

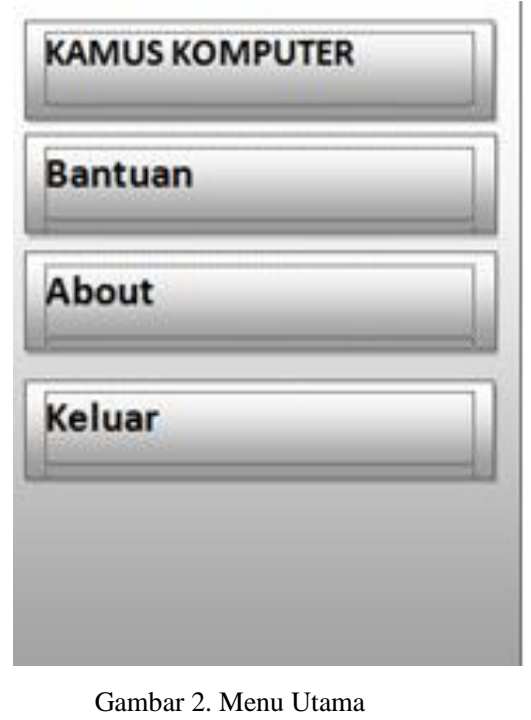

Pada rancangan antarmuka menu kamus istilah komputer akan menampilkan sebuah list view yang berisi data-data kamus istilah-istilah komputer. Pada halaman ini juga terdapat sebuah text field yang digunakan untuk menerima input dari user sebagai patern yang akan diproses untuk pencarian kata. Selain text field, pada halaman ini juga terdapat dua buah button yaitu button cari, yang akan memproses inputan, dan button kembali, 
Jurnal Pseudocode, Volume VII Nomor 1, Februari 2020, ISSN 2355-5920, e-ISSN 2655-1845 www.ejournal.unib.ac.id/index.php/pseudocode

yang digunakan untuk kembali ke halaman sebelumnya.

Adapun rancangan antarmuka menu kamus sebagai berikut:

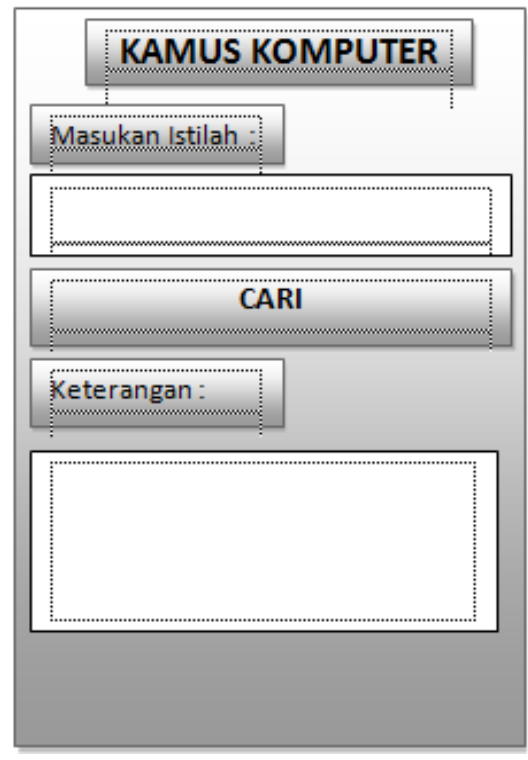

Gambar 3. Menu Pencarian

Adapun flowchart sistem bisa dilihat pada gambar dibawah ini:

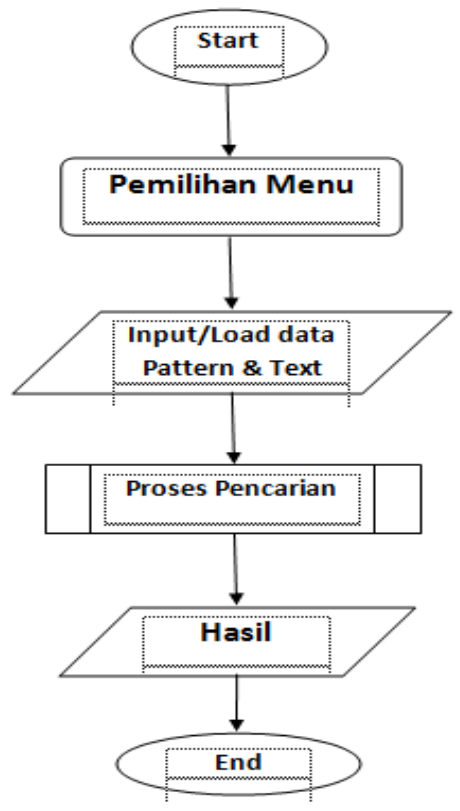

Gambar 4. Flowchart Sistem

\section{HASIL DAN PEMBAHASAN}

Saat aplikasi ini dibuka tampilan pertama yang akan dilihat ialah Menu Utama, seperti yang terlihat pada gambar dibawah:

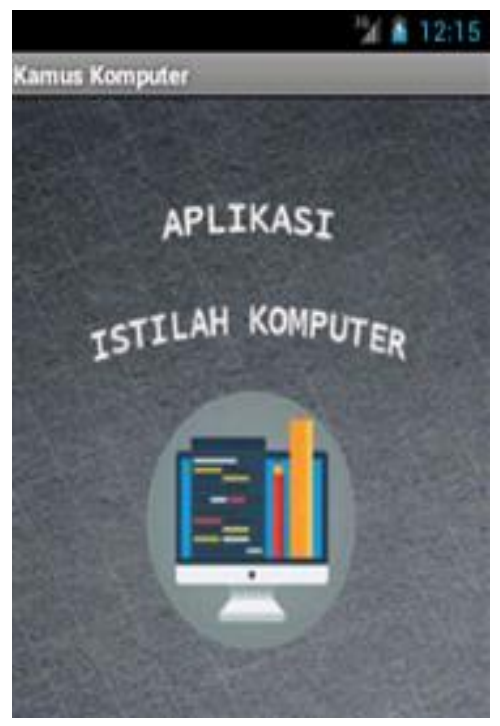

Gambar 5. Antarmuka tampilan pertama

Tampilan Menu Kamus dapat dilihat pada gambar dibawah dimana terdapat empat pilihan sub menu yaitu Kamus Komputer, Bantuan, Tentang dan menu Keluar. Adapun gambar menu kamus sebagai berikut:

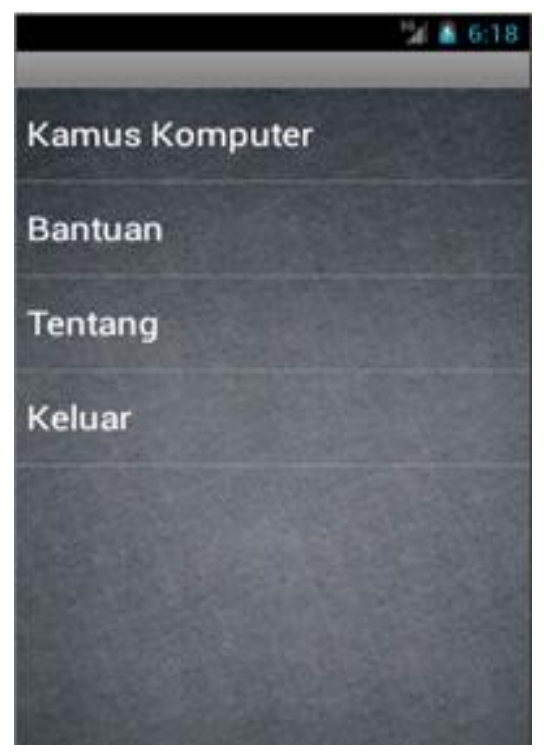

Gambar 6. Menu Kamus

Pada tampilan Kamus Komputer yang dapat dilihat pada gambar dibawah ini, merupakan menu input kata atau pencarian pada istilah komputer. 
Jurnal Pseudocode, Volume VII Nomor 1, Februari 2020, ISSN 2355-5920, e-ISSN 2655-1845 www.ejournal.unib.ac.id/index.php/pseudocode

Dimana pada menu ini pengguna bisa menginputkan kata atau istilah yang akan dicari pada list Inputan Masukan Istilah, kemudian pengguna dapat melanjutkan dengan menekan tombol button "CARI". Adapun gambar sebagai berikut:

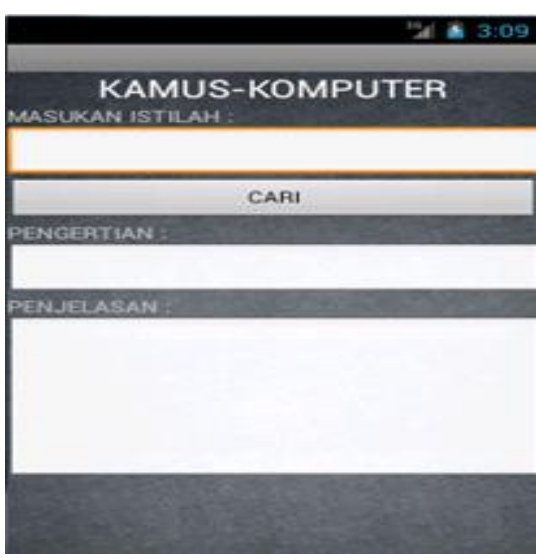

Gambar 7. Input Kata Pada Kamus

Pada Tampilan menu kata ditemukan pada gambar dibawah ini, pengguna telah memasukan kata atau istilah di list inputan kemudian ditekan button "CARI", apabila kata telah disimpan didalam database SQLite maka akan ditampilkan hasil, di list view Pengertian dan akan lebih dijelaskan di list view Penjelasan, untuk memulai lagi proses pencarian pengguna menghapus inputan dan diganti dengan kata yang baru untuk dicari. Adapun tampilannya sebagai berikut:

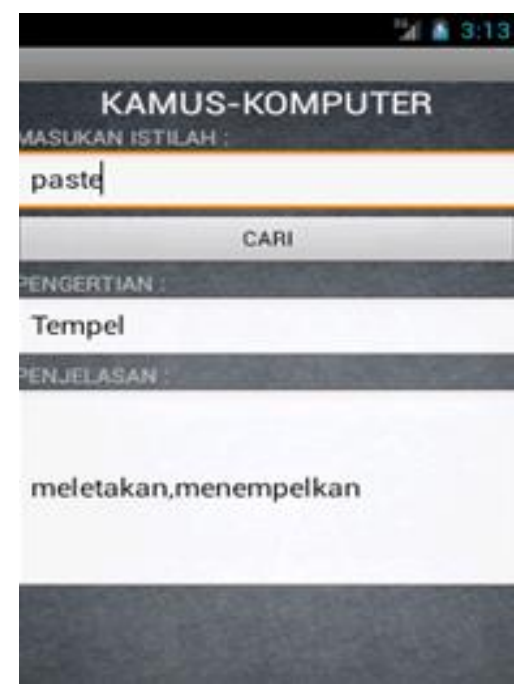

Gambar 8. Kata Ditemukan
Apabila kata sudah terdapat didalam basis data (SQLite) maka kata akan ditampilkan pengertian dan penjelasannya, kemudian kalau tidak didapat didalam database (SQLite) maka akan ditampilkan "Kata Tidak Ditemukan". Adapun tampilannya ialah sebagai berikut:

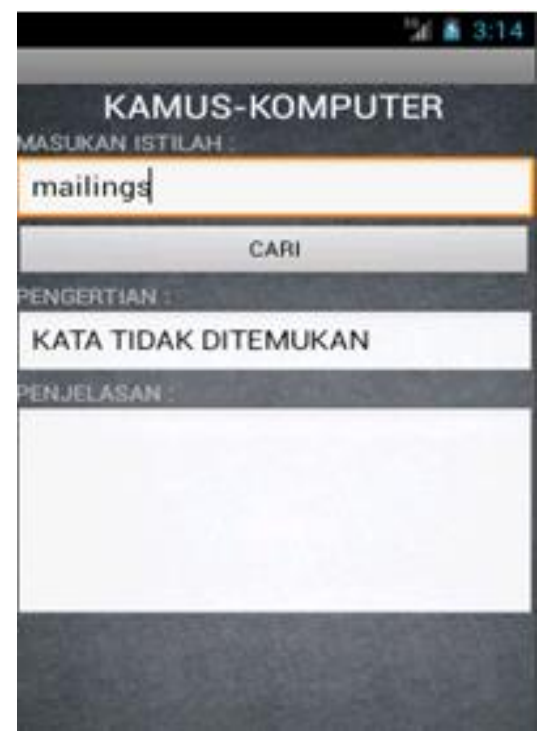

Gambar 9. Kata Tidak Ditemukan

Pada tampilan menu Keluar yang bisa dilihat pada gambar selanjutnya. Apabila pengguna ingin keluar dari aplikasi Kamus Komputer ini, pengguna mengklik button keluar, akan ditampilkan peringatan "Anda yakin ingin menutup aplikasi" makan tekan Ya untuk keluar aplikasi dan tekan Tidak untuk membatalkan. Adapun tampilanya sebagai berikut:

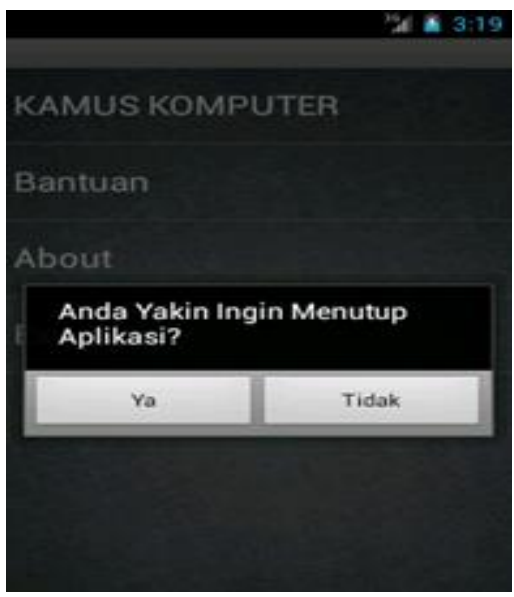

Gambar 10. Menu Keluar 
Pada pembuatan aplikasi Kamus Istilah Komputer ini dimplementasikan atau diterapkannya sebuah algoritme pencarian string, yaitu algoritme Boyer-Moore. Alasan memilih algoritme ini karena algoritme ini adalah algoritme yang paling tepat untuk pencarian dibandingkan dengan algoritme yang lainnya. Kelebihan dari algoritme ini ialah semakin banyak basis datanya maka akan semakin mudah untuk pencarian, dimana akan memakan waktu yang lebih lama bila menggunakan algoritme sederhana. Adapun proses pencarian ialah sebagai berikut:

Tabel 3. Proses Pencarian String Pertama

\begin{tabular}{|c|c|c|c|c|c|c|c|c|c|c|c|c|c|}
\hline $\mathrm{E}$ & $\mathrm{D}$ & $\mathrm{I}$ & $\mathrm{T}$ & $\mathrm{O}$ & $\mathrm{R}$ & & $\mathrm{P}$ & $\mathrm{R}$ & $\mathrm{O}$ & $\mathrm{G}$ & $\mathrm{R}$ & $\mathrm{A}$ & $\mathrm{M}$ \\
\hline $\mathrm{P}$ & $\mathrm{R}$ & $\mathrm{O}$ & $\mathrm{G}$ & $\mathrm{R}$ & $\mathrm{A}$ & $\mathrm{M}$ & & & & & & & \\
\hline
\end{tabular}

Pada tabel di atas ialah proses pencarian kata PROGRAM didalam kamus Istilah Komputer. Dengan melakukan perbandingan dari posisi paling akhir string dapat dilihat bahwa karakter 'M' pada string "PROGRAM" tidak cocok dengan karakter "R" pada string "EDITOR" yang dicari, dan karakter "M" tidak pernah ada dalam string "EDITOR" yang dicari sehingga string "PROGRAM" dapat digeser melewati string "EDITOR", sehingga posisinya seperti berikut.

Tabel 4. Proses Pencarian String Kedua

\begin{tabular}{|c|c|c|c|c|c|c|c|c|c|c|c|c|c|}
\hline $\mathrm{E}$ & $\mathrm{D}$ & $\mathrm{I}$ & $\mathrm{T}$ & $\mathrm{O}$ & $\mathrm{R}$ & & $\mathrm{P}$ & $\mathrm{R}$ & $\mathrm{O}$ & $\mathrm{G}$ & $\mathrm{R}$ & $\mathrm{A}$ & $\mathrm{M}$ \\
\hline & & & & & & $\mathrm{P}$ & $\mathrm{R}$ & $\mathrm{O}$ & $\mathrm{G}$ & $\mathrm{R}$ & $\mathrm{A}$ & $\mathrm{M}$ & \\
\hline
\end{tabular}

Dalam contoh terlihat bahwa algoritme BoyerMoore memiliki loncatan karakter yang besar sehingga mempercepat pencarian string karena dengan hanya memeriksa sedikit karakter, dapat langsung diketahui bahwa string yang dicari tidak ditemukan dan dapat digeser ke posisi berikutnya sehingga ditemukannya kata PROGRAM.

\section{KESIMPULAN DAN SARAN}

Berdasarkan dengan pembahasan dan pengujian dapat diambil kesimpulan sebagai berikut: a. Penelitian telah menghasilkan sebuah aplikasi Kamus Istilah Komputer dimana aplikasi ini bersifat mobile dan dapat dengan mudah dibawah kemana-mana.

b. Dalam penggunaan, aplikasi ini telah dapat menghasilkan informasi tentang istilah-istilah komputer yang selama ini belum banyak yang mengetahuinya

Adapun saran dari penelitian ini adalah:

a. Perlu dibuat adanya sistem sistem online, apabila kata tidak ditemukan didalam basis data, pengguna atau user dapat mencari kata istilah menggunakan mesin pencarian seperti google, yahoo dan lainnya.

b. Aplikasi kamus istilah komputer ini bisa dikembangkan lebih menarik lagi dan juga dapat dikembangkan kamus-kamus lainnya seperti kamus bahasa daerah, beladiri, dan lain sebagainya.

\section{REFERENSI}

[1] K. W. Argakusumah, "Implementasi Algoritme BoyerMoore Pada Aplikasi Kamus Kedokteran Berbasis Android," UMN, p. 01, 2014.

[2] 1. 1. Rinaldi Munir, Algoritme dan pemerograman dalam bahasa pascal, c, dan c++, bandung: informatika, 2016.

[3] Y. Halim Agung, "Implementasi Boyer-Moore Pada Aplikasi Pencarian Rumus Matematika Dan Fisika,” p. 76, 2016.

[4] D. K. Pane, "Implementasi Data Mining Pada Penjualan Produk Elektronik Dengan Algoritme Apriori," Pelita Informatika Budi Darma, p. 26, 2013.

[5] N. Hermanto, "Sistem Pengambilan Keputusan Menggunakan Metode Simple Additive Waighting (SAW) Untuk Menentukan Jurusan Pada SMK Bakti Purwokerto," Seminar Nasional Teknologi dan Informasi, p. 54, 2012.

[6] M. H. Rifqo Dan Y. Apridiansyah, "Implementasi Algoritme Backtracking Dalam Sistem Informasi Perpustakaan Untuk Pencarian Judul Buku (Studi Kasus Unit Pelayanan Terpadu Perpustakaan Universitas Muhammadiyah Bengkulu)," Pseudecode, pp. 90-96, 2017. 
Jurnal Pseudocode, Volume VII Nomor 1, Februari 2020, ISSN 2355-5920, e-ISSN 2655-1845 www.ejournal.unib.ac.id/index.php/pseudocode

[7] M. I. P. Vina Sagita, "Studi Perbandingan Implementasi Algoritme Boyer-Moore, Turbo Boyer-Moore, dan Tuned Boyer-Moore dalam Pencarian String,” p. 31, 2013.

[8] N. A. H. G. L. G. Citra Puji Lestari, "Perangcangan Aplikasi Kamus Istilah Medis Berbasis Android Dengan Algoritme Boyer-Moore,” p. 28, 2016

[9] R. Ramadi, "Pembuatan Aplikasi History Perjalanan GPS Tracker Berbasis WEB Pada Handphone Menggunakan J2ME,”p. 7, 2011.
[10] F. A. Sianturi, "Perancangan Aplikasi Pengamanan Data Dengan Kriptograpi Advanced Encryption Standard (AES)," Pelita Informatika Budi Darma, p. 43, 2013.

[11] R. M. Putra, "Perancangan Aplikasi Kamus Bahasa Minang Berbasis Android," p. 9, 2015.

[12] N. Safaat., Pemrograman Aplikasi Mobile Smartphone dan Tablet PC Berbasis Android, Bandung: Informatika, 2015. 